\title{
The large-scale circulations and summer drought and wetness on the Tibetan plateau
}

\author{
Oliver Bothe, ${ }^{\mathrm{a} *}$ Klaus Fraedrich ${ }^{\mathrm{a}}$ and Xiuhua $\mathrm{Zhu}{ }^{\mathrm{b}}$ \\ a KlimaCampus, Meteorologisches Institut der Universität Hamburg, Grindelberg 5, 20144 Hamburg, Germany \\ b KlimaCampus, Max-Planck-Institut für Meteorologie, Bundesstraße 53, 20146 Hamburg, Germany
}

\begin{abstract}
Effects of large-scale atmospheric circulation and surface temperatures on extreme dryness and wetness on the Tibetan plateau in summer are analysed using ERA-40 reanalysis and observed precipitation. The extreme cases of drought and wetness can be associated with circulation anomalies in the North Atlantic/European sector and wave trains bridging the Eurasian continent. Drought in Tibet reveals an intense high pressure anomaly over Scandinavia supported by a more south-west to north-east orientated North Atlantic stormtrack. This creates wave trains crossing Eurasia which, on their southward 'great circle route', reach south-eastern Asia where they modulate the flow north and east of the Tibetan plateau by an anticyclone-cyclone dipole suppressing moisture supply from the Bay of Bengal.

Wetness in Tibet is characterised by a more zonally oriented cross Atlantic stormtrack creating a low pressure anomaly over central Europe and, associated with it, a northward shift of the sub-tropical westerly and tropical easterly jet; wave trains emerging from the North Atlantic on their equatorward route have now a higher chance to reach the sub-tropical jet entrance (instead of propagating further south). Then the wave trains are re-intensified and, passing the Mediterranean-Arabian Sea route to India, interact with the monsoon's western branch to lead to ample moisture supply for Tibet.

Surface temperatures give indications for positive (negative) El Niño/Southern Oscillation and Indian Ocean Dipole episodes occurring in years of extreme and severe dryness (wetness) on the Tibetan plateau. A pronounced cold surface temperature anomaly in the tropical North Atlantic precedes and accompanies drought on the plateau. Copyright (C) 2009 Royal Meteorological Society
\end{abstract}

KEY WORDS Tibetan plateau; summer monsoon; precipitation; teleconnection; Rossby wave train; Standardized Precipitation Index; drought; wetness

Received 25 September 2008; Revised 6 April 2009; Accepted 8 April 2009

\section{Introduction}

The Tibetan plateau covers an area of half the size of the United States, over two million square kilometres, with an average elevation of about four kilometres. As an elevated heat source and a mechanical barrier, it strongly influences the atmospheric circulation and particularly the climate of Asia by modulating the Asian monsoon circulations (e.g. Flohn, 1964, 1968; Raghavan, 1973; Hahn and Manabe, 1975; Tang and Reiter, 1984; He et al., 1987; Li and Yanai, 1996; Ye and Wu, 1998; Wu and Zhang, 1998; Held et al., 2002; Hsu and Liu, 2003; Zhang et al., 2004; Sato and Kimura, 2007). The close relation between the Tibetan plateau and the Asian monsoon is supported by paleo studies, which show that the summer onshore winds in the Arabian Sea have strengthened between eight and nine million years ago during the uplift of the Tibetan plateau (An et al., 2001).

Precipitation in the Tibetan plateau area is of great importance for the hydrology and agriculture in the downstream river basins of, notably, Ganges, Indus,

\footnotetext{
* Correspondence to: Oliver Bothe, Klimacampus, Meteorologisches Institut der Universität Hamburg, Grindelberg 5, 20144 Hamburg, Germany. E-mail: oliver.bothe@zmaw.de
}

Mekong, Huang He, and Yangtze (Fekete et al., 1999, 2000). The plateau is often regarded as Asia's 'water tower' (Xu et al., 2008), because it serves as the water source of these large Asian rivers.

There are three routes of moisture supply to the Tibetan plateau (Simmonds et al., 1999): (1) the Arabian Sea and Bay of Bengal, (2) the South China Sea, and (3) the mid-latitude westerlies. They are closely linked to the Asian monsoon circulation and further are subject to the influence of long distance teleconnections and stationary wave activity: (i) On the intra-annual timescale, the North Atlantic Oscillation (NAO) has an impact on the temporal and spatial precipitation variability over the eastern part of the Tibetan plateau (Liu and Yin, 2001). (2) On decadal to centennial timescale the North Atlantic multidecadal and the Pacific decadal oscillations affect Eurasia (Ye, 2000; Gupta et al., 2003; Goswami et al., 2006; Zhang and Delworth, 2006, 2007; d'Orgeville and Peltier, 2007; Feng and $\mathrm{Hu}, 2008$ ). (3) Wave train connections have been identified linking the North Atlantic and Europe to Asia and eastern Asia to North America (Ding, 2007). Ding and Wang (2005) describe a circum-global teleconnetion pattern in boreal summer, which they decompose into two conceptual scenarios. 
Scenario-1 incorporates an active Indian summer monsoon forcing a downstream Rossby wave train along the westerly jet, while scenario- 2 describes a Rossby wave train, which is triggered by disturbances in the upstream North Atlantic jet exit region and it travels eastward to Asia influencing the Indian summer monsoon related precipitation. Further wave train patterns between Europe and Asia are described by Sato and Takahashi (2006), and Wakabayashi and Kawamura (2004). These remote wave train connections are usually supported by waveguides along the mid-latitude and sub-tropical jets (see e.g. Hoskins and Ambrizzi, 1993; Ambrizzi et al., 1995).

Tropical sea surface temperature anomalies are a further remote influence on precipitation in South Asia and on the moisture supply to the Tibetan plateau, especially the Indian Ocean Dipole Mode (IOD, Saji et al., 1999) and EI Niño/Southern Oscillation (ENSO, Webster and Yang, 1992). Hong et al. (2008) demonstrate that positive events (positive IOD, El Niño, and both combined) reduce the moisture inflow from the southerly moisture origins (Arabian Sea, Bay of Bengal, southeast monsoon) to the Tibetan plateau while these are strengthened during negative episodes (negative IOD, La Niña, and both combined).

In this note, we focus on severe and extreme drought, and wetness on the Tibetan plateau. These are analysed in their relation to large-scale disturbances. This topic is of interest not only for eastern Asian monsoon research but for climate and seasonal forecasts, and for paleoclimate studies (Zhang et al., 2008; Wang et al., 2008b). Section 2 describes data and methods; in Sections 3 and 4 we analyse composites for extreme and severe dry and wet summer months, discussing the atmospheric flow over Eurasia (Section 3) and the associated surface temperatures (Section 4); Section 5 presents discussions and conclusions.

\section{Data analysis and climatological setting}

Precipitation data is taken from the Vasclimo-climatology (Variability Analysis of Surface Climate Observations, Beck et al., 2005), which spans from 1951 to 2000 with 1.0 by 1.0 degree resolution. Surface (skin temperature) and upper air data (U- and V-wind-velocities, specific humidity, and geopotential on pressure levels) are obtained from ERA-40 reanalysis (September 1957 to August 2002, Uppala et al., 2005). Vasclimo precipitation and ERA-40 circulation data are analysed during the overlapping period 1958 to 2000 on a monthly basis for the summer season (June, July, August) and for preceding three months, respectively.

We are aware that the number of upper-air and surface stations used for the precipitation climatology is low on the western Tibetan plateau. Correlations are about 0.8 between plateau averaged station data for the period 1961 to 2000 and the Vasclimo plateau time series for the same period. Thus, we are confident to present a substantial description of the large-scale influence on the areaaveraged precipitation of the Tibetan plateau. As monthly precipitation differs strongly in various regions on the plateau, the present study adopts the Standardized Precipitation Index (SPI; McKee et al., 1993), which establishes reasonable agreement of point-wise and plateau-averaged drought and wetness classifications. Many studies discuss the influence of local orography and surface conditions on heating mechanisms, precipitation amount, and structure of the atmospheric boundary layer over the plateau (Yeh and Gao, 1979; Yanai and Li, 1994; Ma et al., 2002; Ueda et al., 2003). Here the background flow for the months of extreme wetness and dryness is presented; the interaction of local and regional processes with the large-scale circulation remains for future studies.

\subsection{Tibetan plateau climatological setting}

The circulation above the Tibetan plateau is characterised by the upper level outflow associated with the Tibetan anticyclone and the lower tropospheric flow providing the moisture inflow. The main features of the former are summarised as follows: (1) the divergent flow associated with the tropical Walker type circulation expands over the entire region (Figure 1a), (2) the Tibetan plateau is 'sandwiched' by the summer westerly jet passing to its north and the tropical easterly jet to the south of the Himalayas (Figure 1b), and (3) a warm anticyclone controls the plateau outflow, as indicated by the $300 / 500 \mathrm{hPa}$ thickness (Figure 1b). The zonally asymmetric barotropic component of the upper tropospheric circulation (Figure 1c) is displayed for comparison. The stationary wave activity flux climatology (Plumb, 1985) demonstrates the influence of the circulation upstream and downstream of the Tibetan plateau.

The three origins of moisture supply appear clearly in Figure 1d,e (compare to Simmonds et al., 1999): (1) The Indian monsoon transports moisture from the Arabian Sea and Bay of Bengal onto the Tibetan plateau. This transport becomes particularly important over the plateau where westerly wind and 'gaign' (winds ascending along the western slopes) merge. (2) The south-eastern Asian monsoon and the western North Pacific sub-tropical high direct warm moist air from the South China Sea onto the plateau. (3) The mid-latitude westerlies supply the northern parts of the plateau with moisture. Most areas of Tibet are controlled by convergence (Figure 1d). The eddy water transport (Figure 1e) recycles the mean moisture flux and displays divergence for most parts of China and the plateau. Note that the mean eddy flow is an order of magnitude smaller than the monthly mean flow.

The monthly mean precipitation averaged over the Tibetan plateau (above $2500 \mathrm{~m}$ ) is mainly provided during boreal summer, about 8 to $13 \mathrm{~cm} /$ month, contributing about $70 \%$ of the annual mean (Figure 2, based on Vasclimo). Its standard deviation is about 1 to $2 \mathrm{~cm} /$ month linked to the varying number of synoptic scale systems; for example, one disturbance more (less) may suffice to generate severe wetness (or dryness). 


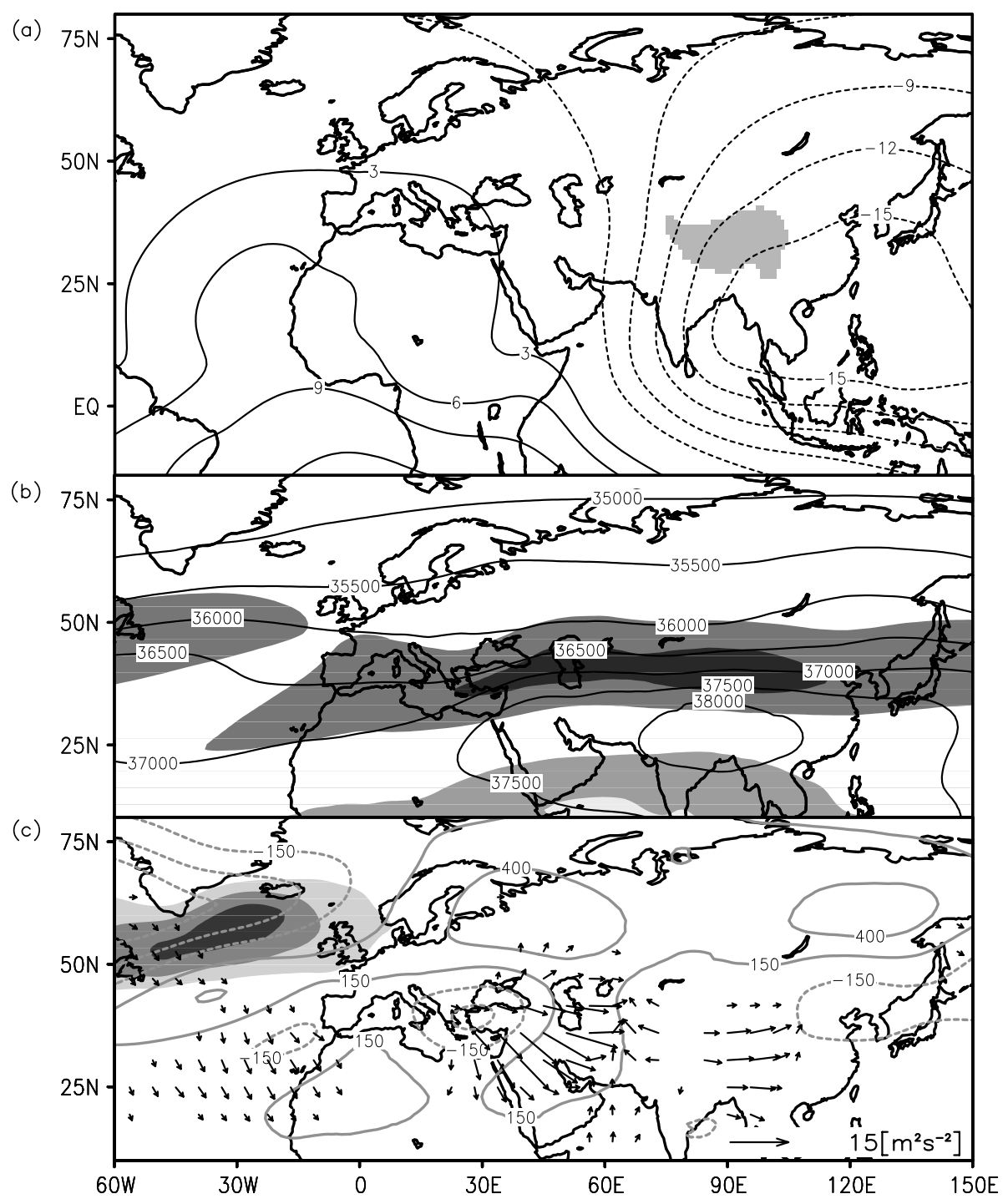

(d)

(e)

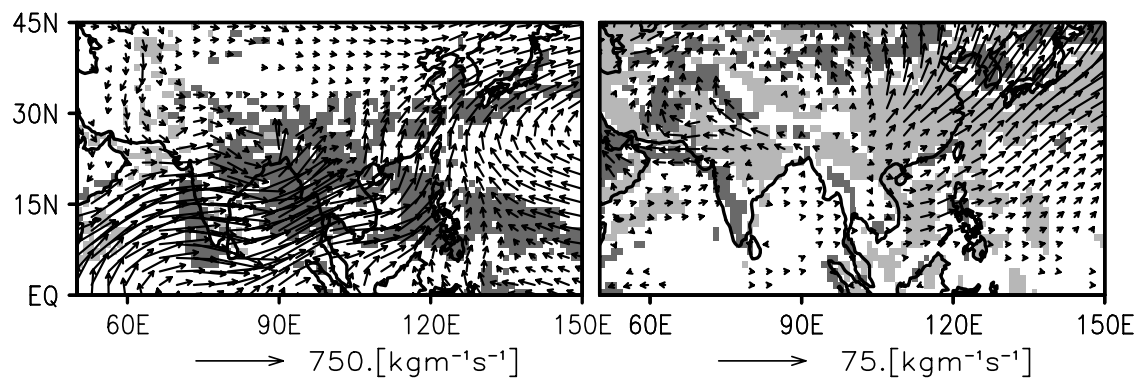

Figure 1. Climatologies of ERA-40 reanalysis (Tibetan plateau shaded): (a) $200 \mathrm{hPa}$ velocity potential (in $\left[10^{-6} \mathrm{~m}^{2} / \mathrm{s}\right]$, contours), (b) $200 \mathrm{hPa}$ zonal wind (in $[\mathrm{m} / \mathrm{s}]$, shaded), the $300-500 \mathrm{hPa}$ layer thickness (contours), (c) $500 \mathrm{hPa}$ stormtrack $\left[10^{2} \mathrm{~m}^{4} / \mathrm{s}^{4}\right]$, shaded, zonally asymmetric barotropic upper tropospheric circulation component $1 / 2\left(300+500 \mathrm{hPa}\right.$ geopotential height), contours in $\left[\mathrm{m}^{2} / \mathrm{s}^{2}\right]$, Plumb's stationary wave flux in $500 \mathrm{hPa}\left(\left[\mathrm{m}^{2} / \mathrm{s}^{2}\right]\right.$, arrows), (d) monthly mean of vertically integrated moisture flux and its divergence [mm/day], and (e) eddy contribution of vertically integrated moisture flux and its divergence. Shades are from light to dark grey in (b) $-20,-10,10$ and 20 and in (c) 900,1200 and 1500. In (d) and (e) divergence and convergence of moisture flux are shaded in light and dark grey above and below $+5(+0.5)$ and $-5(-0.5)$. Arrows of magnitude smaller 1.5, 26 and 2.5 are omitted in (c), (d), and (e), respectively.

\subsection{Standardized Precipitation Index (SPI)}

The SPI (introduced by McKee et al., 1993) is used to classify and monitor dryness and wetness. The calculation of the SPI is based on an 'equal probability transformation': monthly precipitation is transformed to a standard normal distribution to yield SPI values by preserving probabilities (for details see, e.g. Bordi and Sutera, 2001). Standardisation ensures that the SPI gives a uniform measure for dryness and wetness in different climate regimes.

The transformation depends critically on the assumed statistical distribution of monthly precipitation. A false 


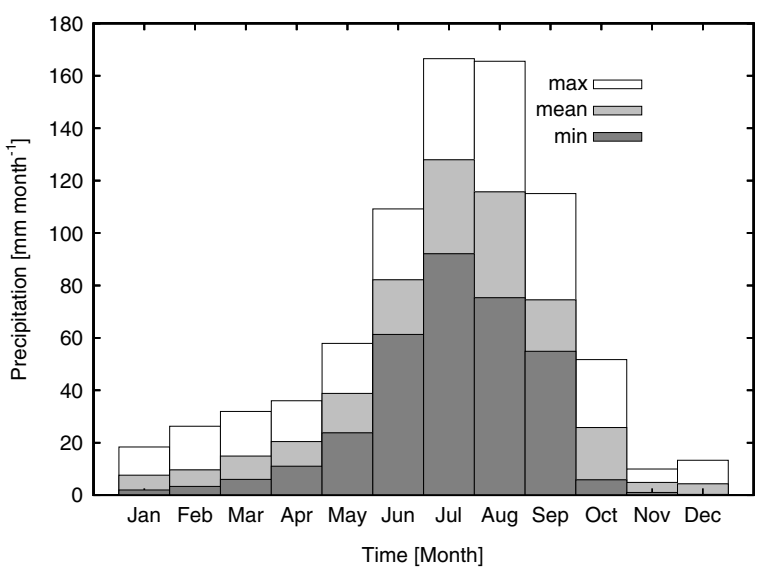

Figure 2. Spatially averaged annual cycle of precipitation (millimetres per month) on the Tibetan plateau (for Vasclimo data); dark shading minimal amount per month, light shading mean amount, clear boxes maximal amount.

distribution type may lead to systematic errors, most pronounced for the extreme cases. That is, the commonly used gamma distribution (Bordi et al., 2007) does not necessarily hold for all months; better fits can be achieved using the Weibull distribution. In order to still use a single unifying distribution type, the 'Generalised Gamma Distribution' is applied instead, employing a reparameterised version (for details, see Sienz et al., 2007).

The SPI can be constructed for different timescales characterising periods of meteorological (months), hydrological (season) and agricultural (year) dryness or wetness. Here we choose the monthly timescale as a meteorologically relevant lower bound for dry and wet spells and their extremes (Dracup et al., 1980). The SPI classification following McKee et al. (1993) is shown in Table I.

\subsection{Tibetan plateau drought and wetness}

The geopotential height and zonal wind fields are regressed onto the SPI to show the synoptic scale flow pattern related to Tibetan plateau dryness and wetness (Figure 3a). Under wet (dry) conditions both the sub-tropical jet over continental Europe and the tropical easterly jet over North Africa shift poleward (equatorward). Over the Tibetan plateau the sub-tropical jet is enhanced (reduced) accompanied by an equatorward (poleward) shift. Simultaneously two anticyclone-cyclone (cyclone-anticyclone) dipoles occur over

Table I. Classification of Standardized Precipitation Index (SPI) and probability ( $p$ in $\%$ ) of events.

\begin{tabular}{llr}
\hline SPI intervals & SPI classes & $p$ value \\
\hline SPI $\geq 2$ & Extremely wet & 2.3 \\
$2>$ SPI $\geq 1.5$ & Severely wet & 4.4 \\
$1.5>$ SPI $\geq 1$ & Moderately wet & 9.2 \\
$1>$ SPI $>-1$ & Normal & 68.2 \\
$-1 \geq$ SPI $>-1.5$ & Moderately dry & 9.2 \\
$-1.5 \geq$ SPI $>-2$ & Severely dry & 4.4 \\
SPI $\leq-2$ & Extremely dry & 2.3 \\
\hline
\end{tabular}

East Asia and western Europe. The centre of the monsoon system shifts westward (eastward) under wet (dry) conditions (Figure 3b), affected by the sea surface temperature anomalies of the neighbouring oceans (e.g. IOD or ENSO; see skin temperature regression in Figure 3c). The western North Pacific monsoon and the Indian summer monsoon (Wang and Fan, 1999; Wang et al., 2001, 2008a) are expected to influence Tibetan plateau precipitation. The correlation of SPI and the western North Pacific Monsoon Index is highly significant (at 99\% level); however, no close relationship with the extreme wet or dry episodes is found. Correlations between the Indian summer monsoon index and plateau SPI are not significant $(90 \%$ level). The data for time series of both indices are obtained from the International Pacific Research Centre (http://iprc.soest.hawaii.edu/ ykaji/ monsoon/index.html).

\section{Tibetan Plateau dryness and wetness: Eurasian flow regimes}

We complement the linear regression analysis with a composite analysis of dry and wet months focussing on the dynamical flow patterns (Section 3) and the boundary conditions (Section 4). In each section, we discuss the regional features of the moisture supply and the larger scale embedding.

\subsection{Extreme and severe dryness}

Six months of severe and extreme drought (SPI $\leq-1.5)$ are identified: June 1961, June 1965, June and August 1972, August 1984, and July 1994. Main features from the anomaly field composites of drought characteristics are summarized as follows:

(1) Over the Tibetan plateau, in particular its central and eastern areas, the water vapour convergence is reduced, associated with a region-wide weakening of the monsoon moisture transport (Figure 4b). The characteristic Indian monsoon and the north-eastward East Asian monsoon moisture flows are reduced. The conflicting positive moisture flux anomaly (Figure $4 \mathrm{~b}$ ) is restricted to the south of the plateau. The upper level moisture flow (not shown) is deflected because of enhanced anticyclonic circumflow around the Himalaya associated with an anomalous high pressure zone in the larger plateau region (Figure 4a). In addition, the monthly mean moisture routes from the south-east and through the Bay of Bengal are suppressed (Figure $4 \mathrm{~b}$ ). These negative flux anomalies are due to enhanced cyclonic activity over the South China Sea. The reduced moisture supply to the plateau coincides with the reduction of upper air outflow and tropical easterly jet (e.g. regression, Figure 3). In addition, the eddy mean component (Figure 4c) indicates moisture transport from the western to the eastern plateau and to the Bay of Bengal. 
(a)

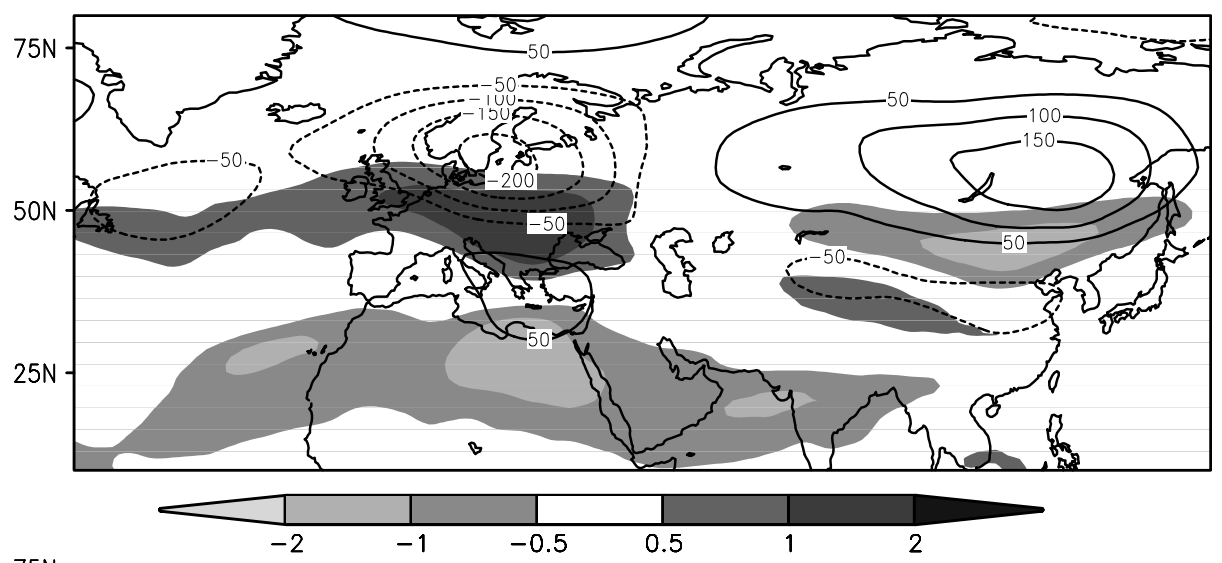

(b)

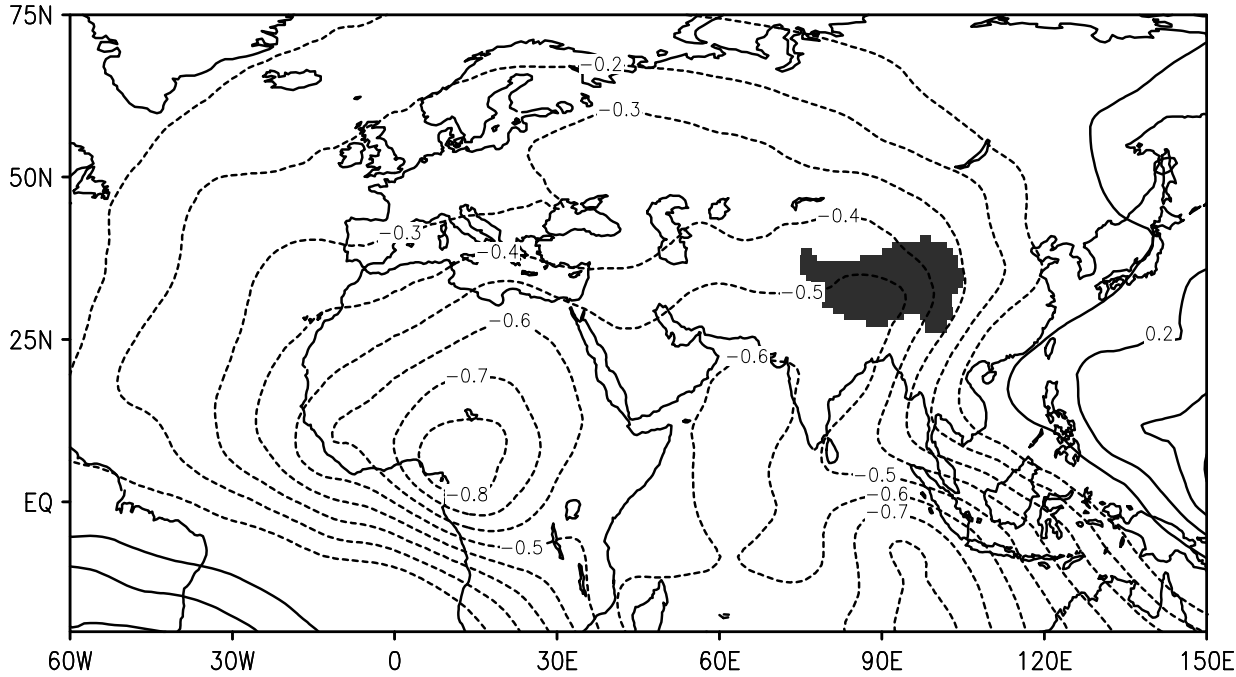

(c)

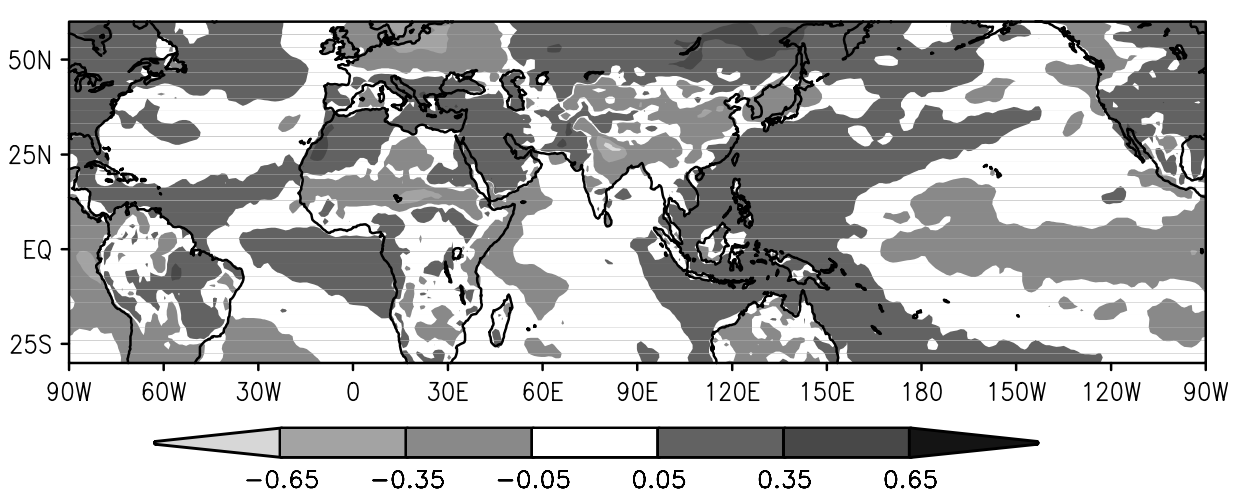

Figure 3. Regression of (a) $200 \mathrm{hPa}$ zonal wind [m/s], shaded, and the $300 \mathrm{hPa}$ geopotential height $\left(\left[\mathrm{m}^{2} / \mathrm{s}^{2}\right]\right.$, contours), (b) $200 \mathrm{hPa}$ velocity potential (in $\left[10^{-6} \mathrm{~m}^{2} / \mathrm{s}^{1}\right]$, contours), Tibetan plateau is marked (shaded), and (c) skin temperature $[\mathrm{K}]$ against the Tibetan plateau SPI series.

(2) The dry case dynamics is related to stationary and transient eddy activity bridging the North Atlantic and the Eurasian continent (Figure 4a). A marked wave train commences from a high pressure anomaly over Scandinavia and extends to the South China Sea. There, a cyclonic anomaly affects (the eastern/southeastern part of) the Tibetan plateau (Figure 4a). This anomalous cyclone deflects the moisture supply from the South China Sea and Bay of Bengal (Figure 4b). The wave train is a manifestation of basically (equivalent) barotropic dynamics (not shown). This Rossbylike wave train is initiated by the strong anticyclonic anomaly over northern Europe/Scandinavia
(Figure 4a): this corresponds to the reduction of the mid-latitude westerly jet intensity over Europe and a strong northern European anticyclone as shown in the regression analysis (Figure 3a). This wave train is clearly detectable in the stationary wave activity flux anomalies (Figure 4a) and in the extended horizontal Eliassen-Palm-Flux (Hoskins et al., 1983; not shown). The anomalous anticyclone over Scandinavia is supported by transient eddy activity (not shown) of the south-west/north-east orientated North Atlantic storm track which, in turn, is influenced by a large positive surface pressure anomaly in the central North Atlantic (not shown). The wave train 
(a)

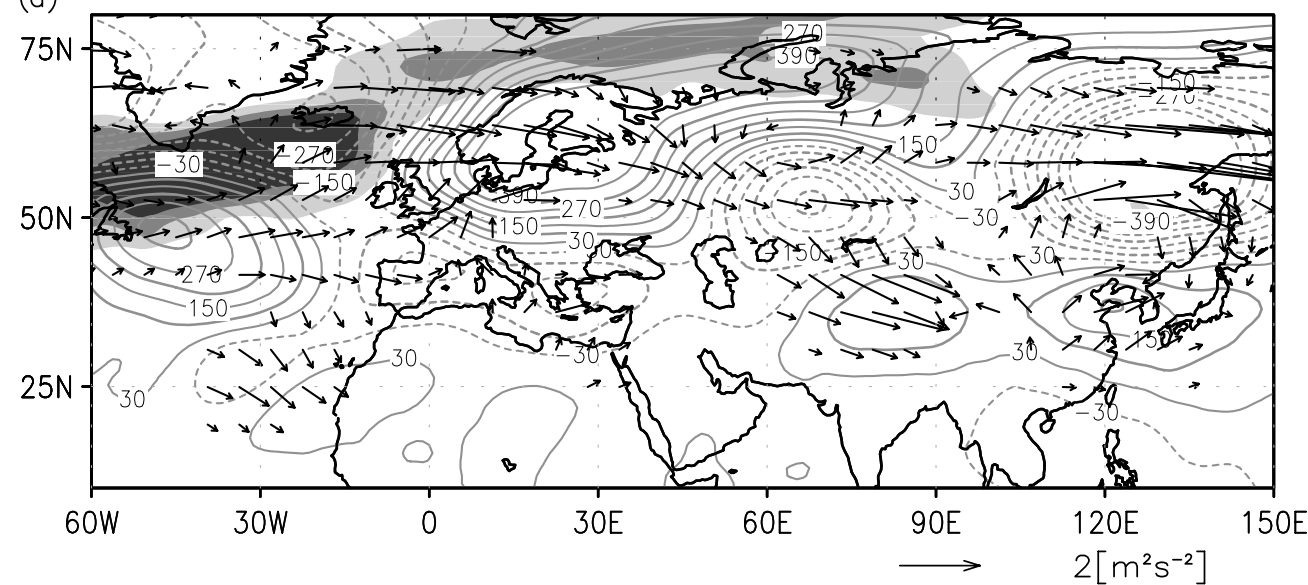

(b)

(c)

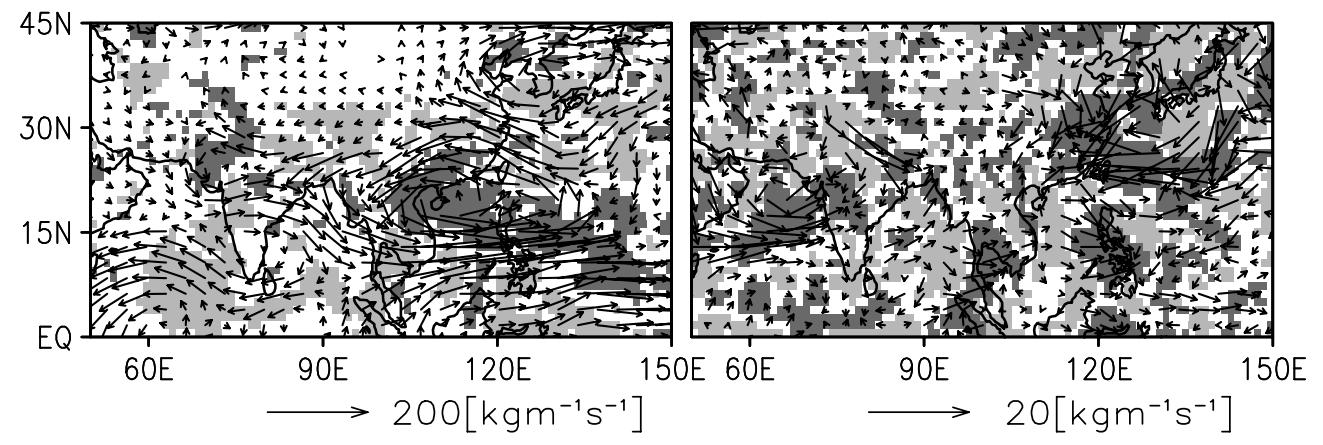

Figure 4. Dry case composites: (a) the storm track on $500 \mathrm{hPa}$ as variance of geopotential height (shaded, shades are 900,1200 and $1500 \mathrm{~m}^{4} / \mathrm{s}^{4}$ ), zonally asymmetric barotropic upper tropospheric circulation component $(1 / 2[300+500 \mathrm{hPa}$ geopotential height]) anomalies (contour intervals are $\left.60 \mathrm{~m}^{2} / \mathrm{s}^{2}\right)$, and anomalies of Plumb's stationary wave flux in $500 \mathrm{hPa}\left(\left[\mathrm{m}^{2} / \mathrm{s}^{2}\right]\right.$, arrows), (b) monthly mean contribution of vertically integrated moisture flux and its divergence [mm/day], and (c) eddy contribution of vertically integrated moisture flux and its divergence. In (b) and (c) divergence and convergence of moisture flux are shaded in light and dark grey above and below $+1.25(+0.25)$ and $-1.25(-0.25)$. Arrows of magnitude smaller $0.2,2.5$ and 0.25 are omitted in (a), (b), and (c), respectively.

transports stationary wave energy from Scandinavia via the Caspian Sea region to the Tibetan plateau.

Fraedrich and Müller (1992; see also Fraedrich, 1994) report northern winter and spring anomalous European circulation features affected by ENSO extremes (similar to the Scandinavian high anomalies found for extreme dryness) which persist throughout the following boreal spring and summer seasons. While the influence of ENSO on Europe is subject to ongoing research (Brönnimann, 2007), the present analysis finds no Scandinavian geopotential height anomalies in boreal summer simultaneous with ENSO, nor a leading role of ENSO.

\subsection{Extreme and severe wetness}

The eleven summer months of Tibetan plateau wetness (severe and extreme wet SPI classes) are August 1958 and 1962, June 1971, 1973 and 1978, July 1981, June 1984, August 1991, July 1996, August 1998, and June 2000. The occurrence of comparatively fewer (six) months of severe and extreme drought (Vasclimo-ERA-40 period) is related to an increase of very wet summer months in the late 20th century (1996 to 2000). The following results are obtained:
(1) The moisture inflow onto the plateau through all three pathways is enhanced (Figure 5): (i) In the midlevels a westward enlarged western North Pacific sub-tropical high allows moist air from the South China Sea to reach the plateau but, more importantly, (ii) wet air is directed from the Arabian Sea onto the plateau along the mid-level cyclonic anomaly over the Arabian region and central Asia. (iii) In low levels this anomaly reaches the Bay of Bengal deflecting moist southerly flow onto the plateau. Thus the eleven summer months of (at least severe) wetness are characterized by larger-than-average moisture inflow along these anomalies accompanied by strengthened Asian monsoon water vapour transport throughout the region.

(2) The water vapour flux anomalies described above are influenced by transient and stationary wave activity. A zonally orientated wave like pattern emerges from the North Atlantic region, extends along $30^{\circ} \mathrm{N}$ and stretches to the western North Pacific south of the large cyclone-anticyclone dipole over northern Eurasia (Figure 5a). This wave train commences in the southern part of the North Atlantic storm track and moves along the jet to the eastern Mediterranean (Figure 5a). The stationary wave activity flux 
(a)

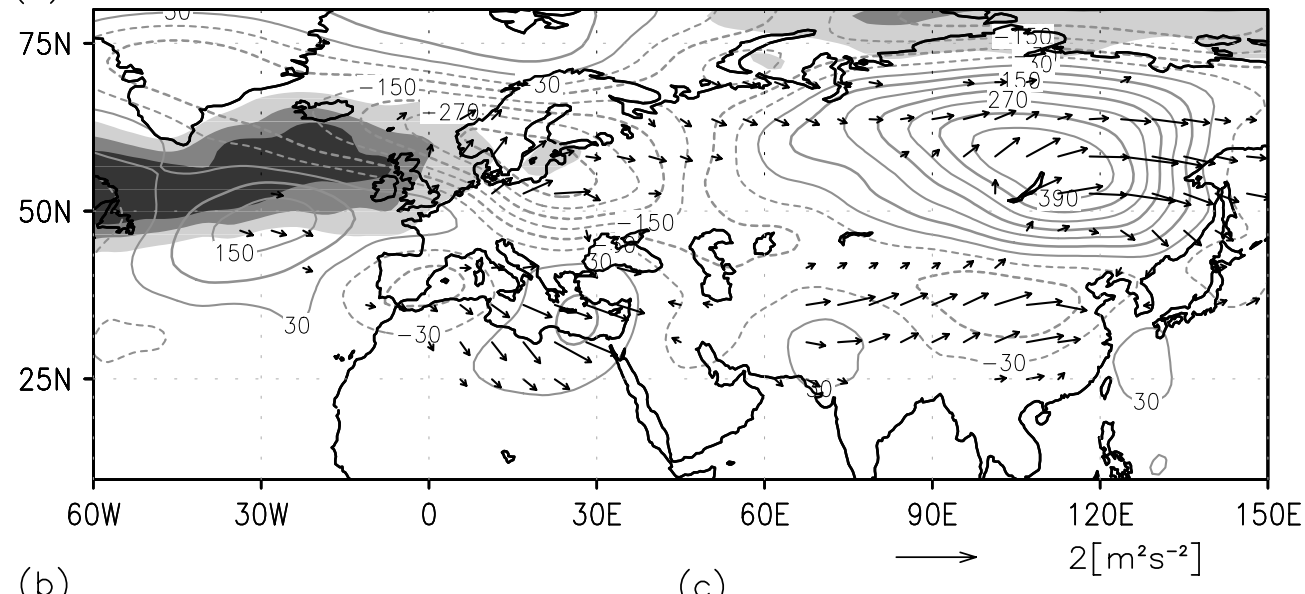

(b)

(c)

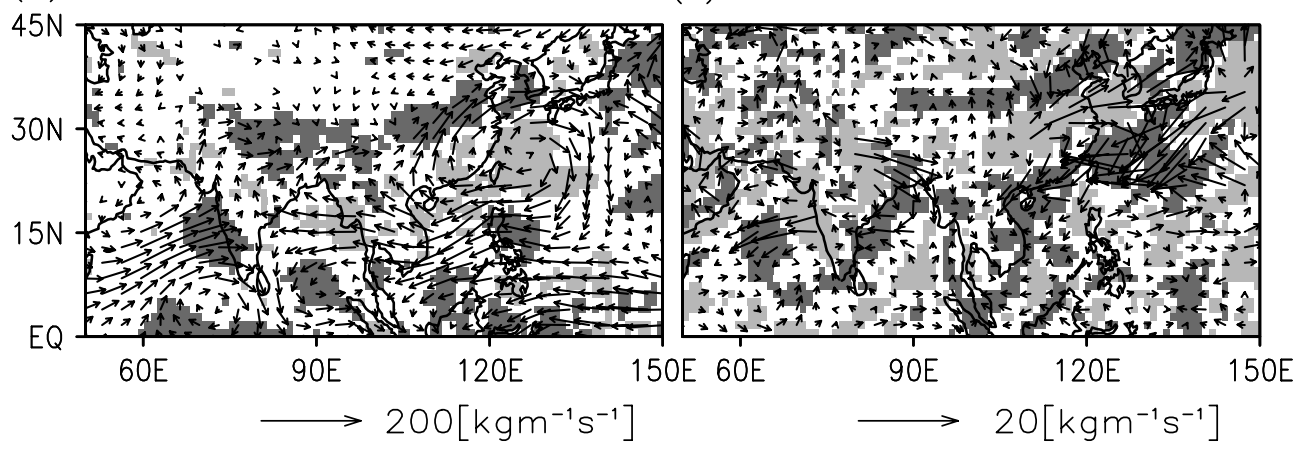

Figure 5. Wet case composites: (a) the storm track on $500 \mathrm{hPa}$ as variance of geopotential height (shaded, shades are 900,1200 , and $1500 \mathrm{~m}^{4} / \mathrm{s}^{4}$ ), zonally asymmetric barotropic upper tropospheric circulation component $(1 / 2[300+500 \mathrm{hPa}$ geopotential height]) anomalies (contour intervals are $\left.60 \mathrm{~m}^{2} / \mathrm{s}^{2}\right)$, and anomalies of Plumb's stationary wave flux in $500 \mathrm{hPa}\left(\left[\mathrm{m}^{2} / \mathrm{s}^{2}\right]\right.$, arrows), (b) monthly mean contribution of vertically integrated moisture flux and its divergence [mm/day], and (c) eddy contribution of vertically integrated moisture flux and its divergence. In (b) and (c) divergence and convergence of moisture flux are shaded in light and dark grey above and below $+1.25(+0.25)$ and $-1.25(-0.25)$. Arrows of magnitude smaller $0.2,2.5$ and 0.25 are omitted in (a), (b) and (c), respectively.

anomaly is weaker than in the dry case. The fluxes from the Atlantic to the eastern Mediterranean and from the Tibetan plateau region eastwards are evident. Thus the wave train diffuses between the subtropical and the tropical easterly jets at the critical latitude of zero zonal velocity (not shown). A secondary wave train emerges from the larger Arabian region and western Asia, where cyclonic anomalies prevail, and stretches along the border between the northward displaced sub-tropical westerly and tropical easterly jets (compare Figure 3). Although these two patterns are not marked as significant ( $90 \%$ level, $t$-test) on all pressure levels, the Mediterranean wave train is fully established in the $850 \mathrm{hPa}$ geopotential (not shown) and the full range of both patterns is best visible in the zonally asymmetric component of the $300 \mathrm{hPa}$ geopotential (compare later Figure $7 \mathrm{~h}$ ). Note that, simultaneously, the upper outflow and the tropical easterly jet are strengthened as depicted by the regression analysis (Figure 3).

3.3. Identification of wave trains on sub-seasonal scale: summer 1984

In this section, we discuss the sub-seasonal atmospheric features for dry and wet episodes on the Tibetan plateau.
We select summer 1984 as a case study to trace the (1) Scandinavia-East-Asia wave train for severe dryness in August and (2) the Mediterranean wave train for severe wetness in June 1984 in terms of zonally asymmetric 500 and $300 \mathrm{hPa}$ geopotential heights.

(1) Scandinavia-East-Asia wave train: We select staggered sections (Figure 6c) for the Hovmöller diagram of daily $500 \mathrm{hPa}$ geopotential height anomalies (Figure 6a) to demonstrate the dry wave train connecting northern Europe and South Asia (compare Figure 4a). In the severe dry August 1984 (Figure 6a, days 62 to 92) an anticyclonic anomaly persists over northern and central Europe and cyclonic anomalies exist over central Eurasia and eastern China while north of Tibet and on the Tibetan plateau an anomalous anticyclonic circulation prevails. For June and July (Figure 6a, day 1 to 61) anomalies are less persistent, interrupted by wave train activity, and shifted westward.

A lagged correlation analysis (not shown) of areaaveraged $500 \mathrm{hPa}$ geopotential height $\left(80^{\circ}\right.$ to $100^{\circ} \mathrm{E}$, $30^{\circ}$ to $36^{\circ} \mathrm{N}$ ) with the geopotential height field for August 1984 confirms the development of the 
(a) $Z 500[55: 70 N] \quad[40: 55 N[30: 36 N[25: 40 N]$ (b) Z300 [25:40N] JJA 1984
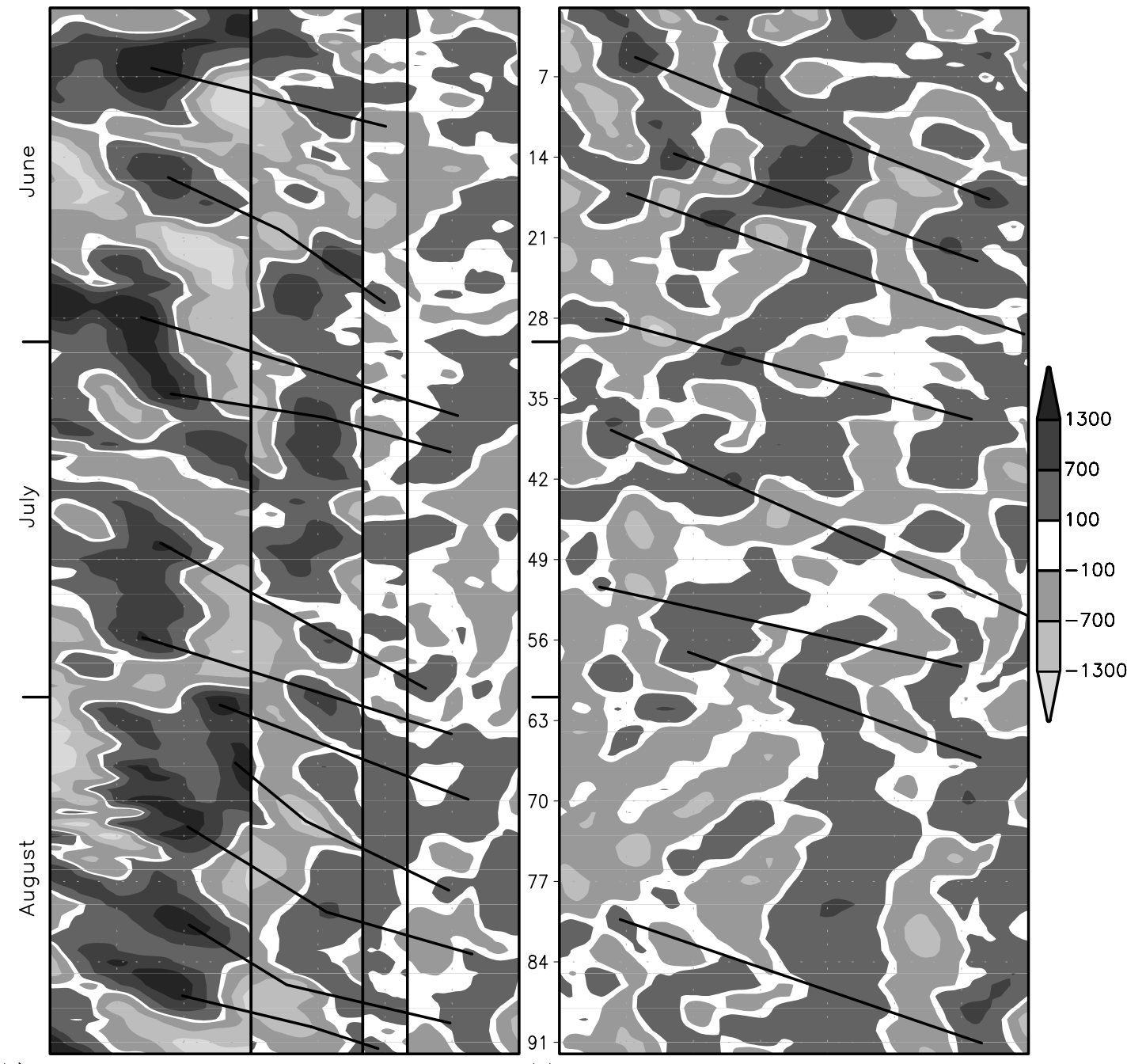

(c)

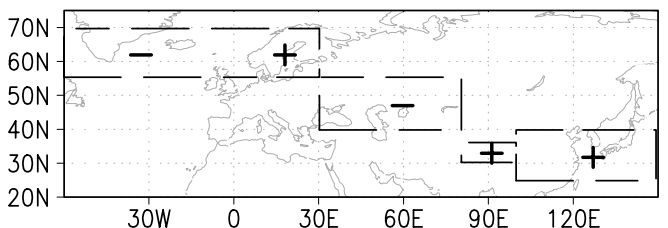

(d)

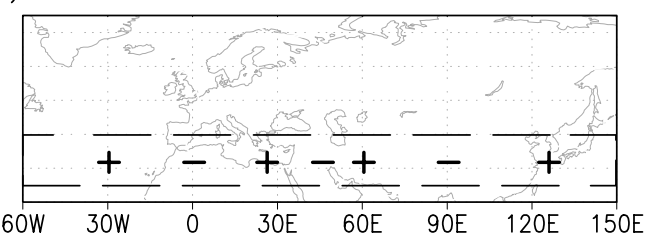

Figure 6. Longitude-time sections (Hovmöller diagram) of zonally asymmetric geopotential height (annual cycle subtracted) for summer 1984: (a) staggered section for $500 \mathrm{hPa}, 60^{\circ} \mathrm{W}$ to $30^{\circ} \mathrm{E}$ averaged $55^{\circ}$ to $70^{\circ} \mathrm{N}, 30^{\circ}$ to $80^{\circ} \mathrm{E}$ mean for $40^{\circ}$ to $55^{\circ} \mathrm{N}, 80^{\circ}$ to $100^{\circ} \mathrm{E}$ average for $30^{\circ}$ to $36^{\circ} \mathrm{N}, 100^{\circ}$ to $150^{\circ} \mathrm{E}$ average for $25^{\circ}$ to $40^{\circ} \mathrm{N}$, (b) $300 \mathrm{hPa}$ section averaged over $25^{\circ}$ to $40^{\circ} \mathrm{N}$, (c) description of boxes used in panel (a), and (d) description of section used in (b). In (c) and (d) plus (minus) indicates anticyclonic (cyclonic) anomalies in Figures 4a and 5a. Lines in (a) and (b) indicate occurrences of Scandinavia-East-Asia pattern or Mediterranean pattern.

anomaly in the plateau region following the development of the Scandinvian high anomaly. The maximum correlation is found for the Scandinavian geopotential height anomaly, leading the Tibetan plateau anomaly by five days.

(2) Mediterranean wave train: The wet wave train (in June 1984) is clearly seen in the Hovmöller diagram (Figure 6b) along the section about $30^{\circ} \mathrm{N}$ (daily $300 \mathrm{hPa}$ geopotential height anomalies averaged over $25^{\circ}$ to $40^{\circ} \mathrm{N}$; see Figure 6d). In June 1984 (Figure 6b, days 1 to 30 ) it displays alternating anticyclonic and cyclonic disturbances along $30^{\circ} \mathrm{N}$ with positive anomalies near $15^{\circ} \mathrm{W}, 40^{\circ} \mathrm{E}$, and $120^{\circ} \mathrm{E}$, negative ones at $0^{\circ}$ and occasionally near $60^{\circ} \mathrm{E}$ and $90^{\circ} \mathrm{E}$. This is emphasized by comparing the dry August (days 62 to 92 ) and the wet June (days 1 to 30 ). Note that in August (with severe dryness) disturbances travel westward from eastern Europe/central Asia $\left(30^{\circ} \mathrm{E}\right.$ to $\left.60^{\circ} \mathrm{E}\right)$ to the Atlantic region.

\section{Tibetan Plateau dryness and wetness: surface temperature conditions}

Here we analyse the persistent surface (skin) temperature anomalies preceding Tibetan plateau dryness and wetness 
(a)

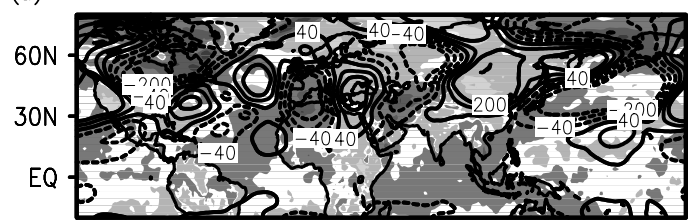

(b)

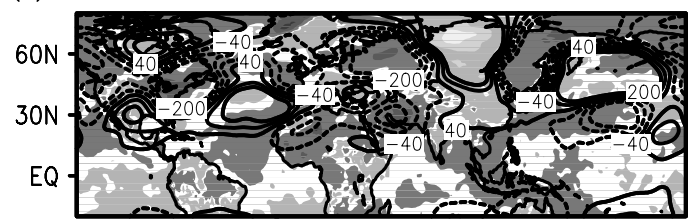

(c)

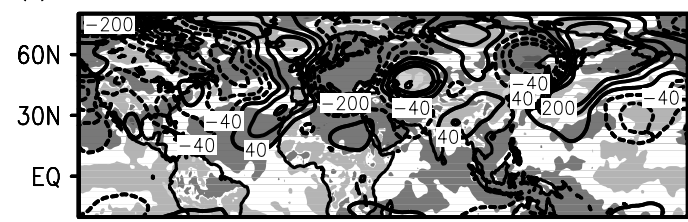

(d)

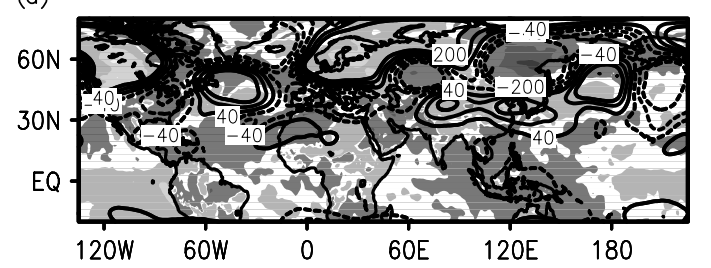

(e)

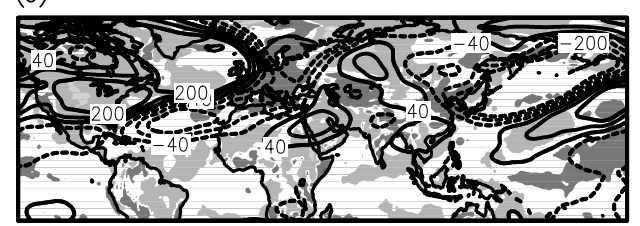

$(f)$

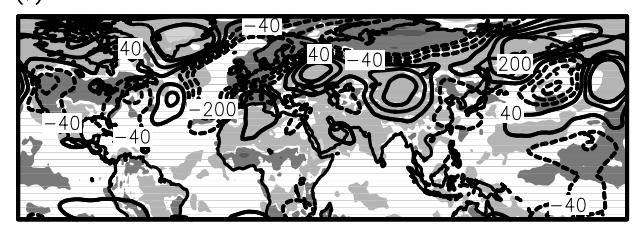

(g)

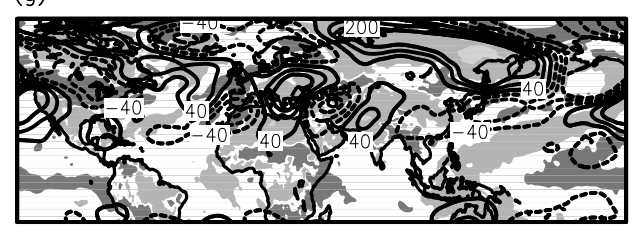

(h)

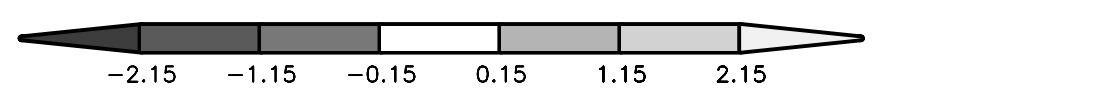

Figure 7. Composited anomalies for months preceding wet and dry episodes of ERA-40 skin temperature (in [K], shaded) and zonally asymmetric $300 \mathrm{hPa}$ geopotential height (in $\left[\mathrm{m}^{2} / \mathrm{s}^{2}\right]$, contours): (a) dry-3 months, (b) dry-2, (c) dry-1, (d) dry, (e) wet-3 months, (f) wet-2, (g) wet-1, and (h) wet.

up to three months, which influence the monsoon and the hemispheric circulation.

\subsection{Extreme and severe dryness}

The simultaneous skin temperature composite (Figure 7d) reflects the overlying atmospheric flow anomalies: anomalous warm conditions over Scandinavia, Tibet, and East China, and cold anomalies in East Siberia, South China, the Mediterranean, and central Eurasia. In the tropical North Atlantic a large statistically significant cold SST-anomaly occurs. This anomalous cold pool is seen in months preceding dryness (dry-1, dry-2, dry-3; Figure $7 \mathrm{a}-\mathrm{c}$ ) and extends temporarily from the tropical North Atlantic to the western slope of the Himalayan mountains. Apparently, this North Atlantic cooling initiates atmospheric anomalies (blocking, Figure $7 \mathrm{a}-\mathrm{d}$ ), deflecting the jet and stormtrack positions (see Section 3 ). That is, we propose the persistent cooler state of the tropical Atlantic as the necessary precursor of a northward deflected stormtrack and, subsequently, a strong Scandinavian high. This view agrees with the vertical anomaly structure (not shown) which presents a significant cooling throughout the troposphere. This negative anomaly is interpreted as cold-monopole forcing (Walter et al., 2001). Simmons et al. (1983) and Walter and Graf (2002) discuss possible influences of tropical North Atlantic SST anomalies on North Atlantic climate teleconnections for boreal winter. How tropical North Atlantic SST and other factors interact in boreal summer to force North Atlantic and Eurasian teleconnection patterns is a subject of ongoing research. Kucharski et al. $(2007,2008)$ emphasise an Atlantic forced component of the Indian summer monsoon. They localize the south equatorial tropical part of the Atlantic, that is the Gulf of Guinea, as the main forcing for the non-ENSO-driven variability of the Indian monsoon rainfall. This region is prominently represented in the regression analysis (Figure 3c), which represents the linear influence on Tibetan plateau precipitation, but there is no signal in the composite analysis for wet and dry extreme episodes.

Tropical skin temperature composites (Figure 7d) indicate a positive IOD phase with warming (cooling) in the equatorial western (eastern) Indian Ocean and an El Niño. Three (out of the six) dry months during the ERA-40 period coincide with positive IOD events (1961, 1972, 1994) and, superimposed, two of them $(1972,1994)$ with positive ENSO events (Niño Index of NOAA's Climate Prediction Center, NOAA, 2008). The most persistent of the regional tropical anomalies is the significantly cooler maritime continent (Figure 7a-d). Tropical SST anomalies (e.g. positive IOD, warm ENSO) appear to have a strong effect on the three moisture paths to the 
Tibetan plateau (Hong et al., 2008). Both, positive IOD and ENSO events, prohibit moisture inflow from the south-east and, if concurrent, they strongly deflect the inflow through the Arabian Sea and the Bay of Bengal. Especially the cold anomalies from the maritime continent to the Bay of Bengal and the East China Sea promote anomalous moisture divergence on the Tibetan plateau (northerly wind anomalies from the continent to the Bay of Bengal, anomalous cyclonic circulation over the South China Sea).

\subsection{Extreme and severe wetness}

Wetness composites show northern Europe to be slightly colder compared to the climatology, while northern Asia is warmer (Figure $7 \mathrm{~h}$, skin temperature) reflecting the atmospheric anomalies. Additionally, an anomalous warm pool is visible in the tropical to sub-tropical western Pacific.

More importantly, a negative IOD phase (cold western tropical Indian Ocean, warm eastern tropical Indian Ocean) may coincide with La Niña (Figure 7h). Associated warm anomalies in the maritime continent are extending northward to the eastern China Sea (Figure 7h). These significant $(t$-test) warm anomalies influence the moisture transport to the Tibetan plateau (see below and Hong et al., 2008). Scatter diagrams of the IOD-Mode index and a variety of ENSO-indices versus the Tibetan plateau SPI show that months of extreme and severe wetness tend to coincide with negative IOD and cold ENSO events (not shown). Correlation coefficients are significant at $95 \%$ level; therefore, the possibility that IOD and ENSO are linked to our extreme and severe events cannot be excluded.

Hong et al. (2008) support the above statements: La Niña, combined with a negative Indian Ocean Dipole, enhances moisture inflow through all southerly routes. A warmer eastern Indian Ocean and maritime continent (extending to the eastern China Sea) enhance the local convective activity: the enhanced western North Pacific sub-tropical high extends further west carrying more moisture from the warmer western Pacific via Indochina into the Bay of Bengal and to the plateau. Note that the evolution of the described surface temperature anomalies can be seen in the three months preceding severe wetness on the plateau (Figure $7 \mathrm{e}-\mathrm{g}$ ).

Shaman and Tziperman (2005) describe, how wintertime ENSO affects the accumulation of snow on the plateau. Thus the meridional land-sea temperature contrast is changed, which drives the south Asian summer monsoon circulation. In addition, the plateau's sensible and latent heating is modified. However, the present study shows no strong relations (correlations and conditional composites, not shown) between extreme wet and dry conditions on the plateau and preceding wintertime ENSO or snow depth.

\section{Summary and discussion}

The present study analyses processes affecting boreal summer variability of pluvial conditions on the Tibetan plateau. Dryness (wetness) on the plateau is accompanied by reduced (enhanced) water vapour convergence (Figures $4 \mathrm{~b}, \mathrm{c}$ and $5 \mathrm{~b}, \mathrm{c}$ ) due to weakened (amplified) moisture transport (Figures $4 a$ and 5a) from all three climatological inflow routes associated with the combined effects of the surface temperature and large-scale atmospheric circulation anomalies.

Related zonal shifts of the monsoon circulation (Figure $3 \mathrm{~b}$ ) are connected with sustained thermal anomalies of the maritime continent (Figure 7), which, in turn, can be attributed to the occurrence of episodes of IOD and/or ENSO. Tropical ocean surface conditions (Figure 7) fit the description by Hong et al. (2008) of IOD and ENSO impacts on Asian moisture fluxes. Surface temperature anomalies reach northward to the East China Sea and modify the western North Pacific subtropical high (e.g. Figure 5b) leading to additional moisture flux (see also Chang et al., 2000a,b).

Upstream and mid-latitude modification of the Asian monsoon is subject to intense research. For Tibetan plateau drought a wave train bridges Eurasia from Scandinavia to East China (Figures 4a, 6a, and 7d). During months of wetness (Figures 5a, 6b, and 7h) conditions in the North Atlantic favour the development of an anomalous short zonal wavelength wave train in the Mediterranean region due to enhanced mid-latitudinal flow over Europe between $50^{\circ}$ and $60^{\circ} \mathrm{N}$ (consistent with Liu and Yin, 2001). This pattern occurs prior to the Tibetan plateau wetness events (Figure $7 \mathrm{~g}$ ). Considering the Eurasian bridging, transient eddy activity in the North Atlantic storm track supports a Scandinavian anticyclone. A cold surface anomaly in the tropical North Atlantic (Figure $7 \mathrm{a}-\mathrm{d}$ ) contributes to the position and orientation of the storm track via associated persistent atmospheric anomalies, which are best seen in the surface pressure (not shown) and the overlying circulation (Figure 7a-d). A northward displacement of the westerly jet in East Asia due to contrasting thermal anomalies in middle and high latitudes supports the dry event wave train in the proximity of the plateau.

The sub-monthly development of the wave train patterns (Figures 4a, 5a, 6, and 7d,h) remains for further studies. Striking is their similarity to prevalent atmospheric fluctuations in boreal winter. Blackmon et al. (1984) describe inter alia 'intermediate' mobile wave trains with north-west/south-east orientation (zonal wavenumber four to six, period of under a month) and zonal high frequent baroclinic fluctuations (zonal wavenumber six to nine, period lower than a week). The former is similar to the dry event wave train (Figures $4 \mathrm{a}$ and $7 \mathrm{~d}$ ) and the latter to the wet Mediterranean wave train (Figures $5 \mathrm{a}$ and $7 \mathrm{~h}$ ). One or two occurrences of the 'fast' wave train could classify a month as being wet, while only one geographically and temporally persistent 'intermediate' pattern could cause a drought event on the 
Tibetan plateau. Although wave train patterns connecting Europe and Asia have been found previously, the explicit links between dryness and wetness on the Tibetan plateau and the Atlantic Ocean via wave train features have not been noted so far.

The Scandinavia-East-Asia pattern also resembles the European part of the circum-global teleconnection described by Ding and Wang (2005). According to them, barotropic instability in the North Atlantic jet exit triggers anomalous high pressure over North or West Europe, which affects the Asian monsoon via Rossby wave trains. As the stormtrack shows an anomalous south-west/northeast orientation for drought events on the Tibetan plateau, the dry pattern may be interpreted as spatially shifted occurrence of this mechanism. This is in accordance with Ding and Wang (2005), who accept the possibility that the upstream (Eurasian) part of the circum-global teleconnection triggers a strong upper level anticyclonic anomaly and, subsequently, a strong Indian monsoon.

James and Hoskins (1985) identify the eastern Mediterranean as a possible example for an internal baroclinic instability mechanism. Rodwell and Hoskins (1996, 2001) describe a connection between Asian monsoon heating and the dynamics of deserts as well as the atmospheric circulation in the Mediterranean region. There, Ziv et al. (2004) find negative correlations with the monsoon (leading by 1 day) using interdiurnal vertical pressure-velocity variations. In the present study computing correlations between ERA-40 daily summer monsoon ascent and Mediterranean descent (same regions as Ziv et al., 2004, different level) yields no significance for most years with Tibetan extreme episodes (not shown). For example, in the case study of 1984 only the dry August displays the monsoon leading as described by Ziv et al. (2004). The impact of extreme daily, as well as climatological, episodes of monsoon heating remains for further research.

In summarizing, the present study shows that conditions upstream and downstream of the Tibetan plateau are relevant for the development of south-eastern Asian rainfall: The anomalous state of the North Atlantic Ocean concurrent with SST anomalies in the Indo-Pacific region are associated with drought and wetness on the Tibetan plateau. As the persistence of these anomalies matters, they influence the Asian region on longer timescales. Further examination of the impact of the seasonal and annual mean circulations on the regional climate is necessary to resolve the initiating dynamics.

\section{Acknowledgements}

Model and Data Group and NOAA-CPC provided the data. The R Development Core Team (2005) provided the statistics package 'R'. Funding by Deutsche Forschungsgemeinschaft (FR 450/7, FR 450/14-2) is acknowledged. Discussions at TiP-meetings (SPP 1372) and referees' comments are apperciated, which helped improving the manuscript.

\section{References}

Ambrizzi T, Hoskins BJ, Hsu H-H. 1995. Rossby wave propagation and teleconnection patterns in the Austral winter. Journal of the Atmospheric Sciences 52: 3661-3672.

An Z, Kutzbach JE, Prell WE, Porter SC. 2001. Evolution of Asian monsoons and phased uplift of the Himalaya-Tibetan plateau since late Miocene times. Nature 411: 62-66, DOI: 10.1038/35075035.

Beck C, Grieser J, Rudolf B. 2005. A new monthly precipitation climatology for the global land areas for the period 1951 to 2000. Climate Status Report No. 2004, German Weather Service: Offenbach, 181-190.

Blackmon ML, Lee Y-H, Wallace JM, Hsu H-H. 1984. Time variation of 500-mb height fluctuations with long, intermediate and short time scales. Journal of the Atmospheric Sciences 41: 981-991.

Bordi I, Fraedrich K, Petitta M, Sutera A. 2007. Extreme value analysis of wet and dry periods in Sicily. Theoretical and Applied Climatology 87: 61-71, DOI: 10.1007/s00704-005-0195-3.

Bordi I, Sutera A. 2001. Fifty years of precipitation: Some spatially remote teleconnections. Water Resources Management 15: 247-280.

Brönnimann S. 2007. Impact of El Niño-Southern Oscillation on European climate. Reviews of Geophysics 45: RG3003, DOI:10.1029/2006RG000199.

Chang C-P, Zhang Y, Li T. 2000a. Interannual and interdecadal variations of the East Asian summer monsoon and tropical Pacific SSTs. Part I: Roles of the subtropical ridge. Journal of Climate 13: 4310-4325.

Chang C-P, Zhang Y, Li T. 2000b. Interannual and interdecadal variations of the East Asian summer monsoon and tropical Pacific SSTs. Part II: Meridional structure of the monsoon. Journal of Climate 13: 4326-4340.

Ding Y. 2007. The variability of the Asian summer monsoon. Journal of the Meteorological Society of Japan 85B: 21-54.

Ding Q, Wang B. 2005. Circumglobal teleconnection in the northern hemisphere summer. Journal of Climate 18: 3483-3505, DOI: 10.1175/JCLI3473.1.

d'Orgeville M, Peltier WR. 2007. On the Pacific Decadal Oscillation and the Atlantic Multidecadal Oscillation: Might they be related? Geophysical Research Letters 34: L23705, DOI: 10.1029/2007GL031584.

Dracup JA, Lee KS, Paulson EG Jr. 1980. On the definition of droughts. Water Resources Research 16: 297-302.

Fekete BM, Vörösmarty CJ, Grabs W. 1999. Global, composite runoff fields based on observed river discharge and simulated water balances. Technical Report No. 22, Global Runoff Data Center: Koblenz, 115.

Fekete BM, Vörösmarty CJ, Grabs W. 2000. UNH/GRDC composite runoff fields V 1.0. Durham, NH: Complex Systems Research Center, University of New Hampshire, Koblenz, Germany: Global Runoff Data Center (GRDC). See http://www.grdc.sr.unh.edu/.

Feng S, Hu Q. 2008. How the North Atlantic Multidecadal Oscillation may have influenced the Indian summer monsoon during the past two millenia. Geophysical Research Letters 35: L01707, DOI: 10.1029/2007GL032484.

Flohn H. 1964. Investigations on the tropical easterly jet. Bonner Meteorologische Abhandlungen 4: 1-83.

Flohn H. 1968. Contributions to a meteorology of the Tibetan highlands. Atmospheric Science Paper No. 130, Department of Atmosphere Science, Colorado State University: Colorado.

Fraedrich K. 1994. An ENSO impact on Europe? Tellus A 46: 541-552, DOI: 10.1034/j.1600-0870.1994.00015.x.

Fraedrich K, Müller K. 1992. Climate anomalies in Europe associated with ENSO extremes. International Journal of Climatology 12: 25-31, DOI: 10.1002/joc.3370120104.

Goswami BN, Madhusoodanan MS, Neema CP, Sengupta D. 2006. A physical mechanism for North Atlantic SST influence on the Indian summer monsoon. Geophysical Research Letters 33: L02706, DOI: 10.1029/2005GL024803.

Gupta AK, Anderson DM, Overpeck JT. 2003. Abrupt changes in the Asian southwest monsoon during the Holocene and their links to the North Atlantic Ocean. Nature 421: 354-357, DOI: 10.1038/nature01340.

Hahn DG, Manabe S. 1975. The role of mountains in the South Asian monsoon circulation. Journal of the Atmospheric Sciences 32: 1515-1541.

He H, McGinnis JW, Song Z, Yanai M. 1987. Onset of the Asian summer monsoon in 1979 and the effect of the Tibetan plateau. Monthly Weather Review 115: 1966-1995. 
Held IM, Ting M, Wang H. 2002. Northern winter stationary waves: Theory and modeling. Journal of Climate 15: 2125-2144.

Hong C-C, Lu M-M, Kanamitsu M. 2008. Temporal and spatial characteristics of positive and negative Indian ocean dipole with and without ENSO. Journal of Geophysical Research 113: D08107, DOI: 10.1029/2007JD009151.

Hoskins BJ, Ambrizzi T. 1993. Rossby wave propagation on a realistic longitudinally varying flow. Journal of the Atmospheric Sciences 50: $1661-1671$.

Hoskins BJ, James IN, White GH. 1983. The shape, propagation and mean-flow interaction of large-scale weather systems. Journal of the Atmospheric Sciences 40: 1595-1612.

Hsu H-H, Liu X. 2003. Relationships between the Tibetan plateau heating and East Asian summer monsoon rainfall. Geophysical Research Letters 30(20): 2066, DOI: 10.1029/2003GL017909.

James IN, Hoskins BJ. 1985. Some comparisons of atmospheric internal and boundary baroclinic instability. Journal of the Atmospheric Sciences 42: 2142-2155.

Kucharski F, Bracco A, Yoo JH, Molteni F. 2007. Low-frequency variability of Indian monsoon-ENSO relationship and the tropica Atlantic: The "weakening" of the 1980s and 1990s. Journal of Climate 20: 4255-4266.

Kucharski F, Bracco A, Yoo JH, Molteni F. 2008. Atlantic forced component of the Indian monsoon interannual variability. Geophysical Research Letters 35: L04706, DOI: 10.1029/2007GL033037.

Li C, Yanai M. 1996. The onset and interannual variability of the Asian summer monsoon in relation to land-sea thermal contrast. Journal of Climate 9: 358-375.

Liu X, Yin Z-Y. 2001. Spatial and temporal variation of summer precipitation over the eastern Tibetan plateau and the North Atlantic Oscillation. Journal of Climate 14: 2896-2909.

Ma Y, Su Z, Li Z-L, Koike T, Menenti M. 2002. Determination of regional net radiation and soil heat flux densities over heterogeneous landscape of the Tibetan Plateau. Hydrological Processes 16 2963-2971.

McKee TB, Doeskin NJ, Kleist J. 1993. The relationship of drought frequency and duration to time scales. 8th Conference on Applied Climatology. American Meteorological Society: Anaheim; 179-184.

NOAA. 2008. Previous ENSO Events. [Available online at http://www.cpc.noaa.gov/products/monitoring_and_data/ENSO_ connections.shtml].

Plumb RA. 1985. On the Three-dimensional propagation of stationary waves. Journal of the Atmospheric Sciences 42: 217-229.

Raghavan K. 1973. Tibetan anticyclone and tropical easterly jet. Pure and Applied Geophysics 110: 2130-2142.

R Development Core Team. 2005. R: A language and environment for statistical computing. $R$ Foundation for Statistical Computing, Vienna, Austria, URL http://www.R-project.org.

Rodwell MJ, Hoskins B. 1996. Monsoons and the dynamics of deserts. Quarterly Journal of the Royal Meteorological Society 122 $1385-1404$.

Rodwell MJ, Hoskins B. 2001. Subtropical anticyclones and summer monsoons. Journal of Climate 14: 3192-3211.

Saji NH, Goswami BN, Vinayachandran PN, Yamagata T. 1999. A dipole mode in the tropical Indian Ocean. Nature 401: 361-363.

Sato T, Kimura F. 2007. How does the Tibetan plateau affect the transition of Indian monsoon rainfall? Monthly Weather Review 135 2006-2015, DOI: 10.1175/MWR3386.1.

Sato N, Takahashi M. 2006. Dynamical processes related to the appearance of quasi-stationary waves on the subtropical jet in the midsummer northern hemisphere. Journal of Climate 19 1531-1544, DOI: 10.1175/JCLI3697.1.

Shaman J, Tziperman E. 2005. The effect of ENSO on Tibetan plateau snow depth: A stationary wave teleconnection mechanism and implications for the South Asian monsoons. Journal of Climate 18 2067-2079.

Sienz F, Bordi I, Fraedrich K, Schneidereit A. 2007. Extreme dry and wet events in Iceland: observations, simulations and scenarios. Meteorologische Zeitschrift 16: 9-16.

Simmonds I, Bi D, Hope P. 1999. Atmospheric water vapor flux and its association with rainfall in China in summer. Journal of Climate 12: $1353-1367$.

Simmons AJ, Wallace JM, Branstator GW. 1983. Barotropic wave propagation and instability, and atmospheric teleconnection patterns. Journal of the Atmospheric Sciences 40: 1363-1392.

Tang M, Reiter ER. 1984. Plateau monsoons of the northern hemisphere: A comparison between North America and Tibet. Monthly Weather Review 112: 617-637.
Ueda H, Kamahori H, Yamasaki N. 2003. Seasonal contrasting features of heat and moisture budgets between the eastern and western Tibetan Plateau during the GAME IOP. Journal of Climate 16: $2309-2324$.

Uppala SM, Kallberg PW, Simmons AJ, Andrew U, Da Costa Bechtold V, Fiorino M, Gibson JK, Haseler J, Hemandez A, Kelly GA, Li X, Onogi K, Saarinen S, Sokka N, Allan RP, Andersson E, Arpe K, Balmaseda MA, Beljaars ACM, Van De Berg L, Bidlot J, Bormann N, Caires S, Chevallier F, Dethof A, Dragosavac M, Fisher M, Fuentes M, Hagemann S, Hólm E, Hoskins BJ, Isaksen L, Janssen PAEM, Jenne R, Mcnally AP, Mahfouf J-F, Morcrette J-J, Rayner NA, Saunders RW, Simon P, Sterl A, Trenberth KE, Untch A, Vasiljevic D, Viterbo P, Woollen J. 2005. The ERA-40 re-analysis. Quarterly Journal of the Royal Meteorological Society 131: 2961-3012, DOI: 10.1256/qj.04.176.

Wakabayashi S, Kawamura R. 2004. Extraction of major teleconnection patterns possibly associated with the anomalous summer climate in Japan. Journal of the Meteorological Society of Japan 82: $1577-1588$.

Walter K, Graf H-F. 2002. On the changing nature of the regional connection between the North Atlantic Oscillation and sea surface temperature. Journal of Geophysical Research 107(D17): 4338 , DOI:10.1029/2001JD000850.

Walter K, Luksch U, Fraedrich K. 2001. A response climatology of idealized midlatitude thermal forcing experiments with and without a storm track. Journal of Climate 14: 467-484.

Wang B, Fan Z. 1999. Choice of South Asian Summer Monsoon Indices. Bulletin of the American Meteorological Society 80: $629-638$.

Wang B, Wu R, Lau KM. 2001. Interannual Variability of the Asian Summer Monsoon: Contrasts between the Indian and the Western North Pacific-East Asian Monsoons. Journal of Climate 14: 4073-4090.

Wang B, Wu Z, Li J, Liu J, Chang CP, Ding Y, Wu G. 2008a. How to measure the strength of the East Asian Summer Monsoon. Journal of Climate 21: 4449-4463.

Wang X, Zhang Q-B, Ma K, Xiao S. 2008b. A tree-ring record of 500 -year dry-wet changes in northern Tibet, China. Holocene 18: 579-588, DOI: 10.1177/0959683608089212.

Webster PJ, Yang S. 1992. Monsoon and ENSO: Selectively interactive systems. Quarterly Journal of the Royal Meteorological Society 118: $877-926$.

Wu G, Zhang Y. 1998. Tibetan plateau forcing and the timing of the monsoon onset over South Asia and the South China Sea. Monthly Weather Review 126: 913-927.

Xu X, Lu C, Shi X, Gao S. 2008. World water tower: An atmospheric perspective. Geophysical Research Letters 35: L20815, DOI: 10.1029/2008GL035867.

Yanai M, Li C. 1994. Mechanism of heating and the boundary layer over the Tibetan Plateau. Monthly Weather Review 122: 305-323.

Ye H. 2000. Decadal variability of Russian winter snow accumulation and its associations with Atlantic sea surface temperature anomalies. International Journal of Climatology 20: 1709-1728.

Ye D-Z, Wu G-X. 1998. The role of the heat source of the Tibetan plateau in the general circulation. Meteorology and Atmospheric Physics 67: 181-198.

Yeh T-C, Gao Y-X. 1979. The Meteorology of the Qinghai-Xizang (Tibet) Plateau. Science Press: Beijing, (in Chinese)

Zhang R, Delworth TL. 2006. Impact of Atlantic multidecadal oscillations on India/Sahel rainfall and Atlantic hurricanes. Geophysical Research Letters 33: L17712, DOI: 10.1029/2006GL026267.

Zhang R, Delworth TL. 2007. Impact of the Atlantic Multidecadal Oscillation on North Pacific climate variability. Geophysical Research Letters 34: L23708, DOI: 10.1029/2007GL031601.

Zhang Q, Gemmer M, Chen J. 2008. Climate changes and flood/ drought risk in the Yangtze Delta, China, during the past millennium. Quaternary International 176-177: 62-69, DOI: 10.1016/j.quaint.2006.11.004

Zhang Y, Li T, Wang B. 2004. Decadal change of the spring snow depth over the Tibetan plateau: The associated circulation and influence on the East Asian monsoon. Journal of Climate 17: $2780-2793$

Ziv B, Saaroni H, Alpert P. 2004. The factors governing the summer regime of the eastern Mediterranean. International Journal of Climatology 24: 1859-1871, DOI: 10.1002/joc.1113. 